\title{
Teachers' Beliefs of Authentic Materials for Teaching Reading in Indonesian EFL Classrooms
}

\author{
Desy Rusmawaty \\ State University of Makassar, Makassar, Indonesia \\ Haryanto Atmowardoyo \\ State University of Makassar, Makassar, Indonesia \\ Arifuddin Hamra \\ State University of Makassar, Makassar, Indonesia \\ Nurdin Noni \\ State University of Makassar, Makassar, Indonesia
}

\begin{abstract}
It is believed that authentic reading materials can link students to contextual use of English, as they can improve students' communicative and cultural competences. Related to point, this is very important to highlight the investigation on teachers' beliefs about authentic reading materials as it is reflected through the teachers' expectation and how they manifest them in classroom practices. This is a case study of four teachers who teach English at public senior high school in Samarinda, East Kalimantan. The study explores the beliefs of these teachers about authentic reading materials in their classroom practices. The data were taken from a semi structured interview, classroom observation, and teachers' written documents. The study revealed that there were three themes of teachers' beliefs emerged, (1) types of authentic reading materials, (2) skills to be improved after reading, and (3) teachers' challenges of using authentic reading materials for the classroombases. It is noted that teachers did self-adjustment when manifesting their beliefs in classroom activities. In addition, Teachers needs self-management when utilizing authentic materials.
\end{abstract}

Index Terms - beliefs, English teachers, authentic materials, case study

\section{INTRODUCTION}

Many studies believed that students should have abundance exposures to use of English in real context (Beresova, 2015; Ersanli, 2016, Ahmed, 2017). These exposures are used to fill the need for being able to communicate confidently in English. In fact, Hymes (cited in Beresova, 2015) argued that communicative competence does not merely involve understanding of the language but the necessitate for contextualized communicated and soon it leads to the influences of linguistic and social norm in discourse and speech acts which later on it will act in relation to social structure, values, and social cultural order and the rules of a community. Teachers must provide as many as possible materials with relevant contexts for their students. This is done to provide the choice of words in constructing of meaning. One of materials used is authentic materials.

In fact, selecting authentic materials for language learning, especially for teaching reading in EFL context becomes an issue in language teaching. Teachers are put their concerns on this. They are aware that the use of authentic reading materials can support students to learn and read language in a natural way. From the researcher' observation, it is quite often teachers struggle to search, select, and modify authentic reading materials in their teaching practices. It is necessary for teachers to consider authentic reading materials consist of extensive vocabularies and appropriate sentence structure for their students' level. Learning to read a language in a natural way is conducted by bringing the world outside into a classroom language. This becomes the focus of the functional use of authentic reading materials.

It is often, if not many, when teaching reading text teachers integrated authentic materials in their teaching practices. They are aware that familiarizing reading texts in the real usage contexts provide students with real exposures of English. Students are able to link the knowledge of world outside with the their classroom knowledge (Abdulhussein, 2014; Harmer, 2001; Wong, Kwok, \& Choi, 1995). In addition, authentic reading materials support students to acquire their communicative competence in using English (Guariento \& Morley, 2001).

It is believed that authentic materials are able to stimulate students' motivation to learn. They can support students' opportunities to intermingle with real uses of language rather than artificial materials which are made for learning purposes only. By using authentic materials for teaching, it is expected that students can learn language naturally. Furthermore, "every text that learners encounter should be authentic and that most tasks should be authentic toootherwise the learners are not being prepared for the reality of language use" (Tomlinson, 2012). 
Nevertheless, authentic reading materials are often found to be culturally biased. Teachers admitted that they have to adjust the semantic structure of authentic materials with their students' level (Kilickaya, 2004). This means teachers have to paraphrase certain words found in authentic materials which beyond the students' knowledge with the words that their students familiar with. Certainly, it takes time. Teachers need some effort to take authentic materials as their teaching material. For that reason, this study aims to explore the beliefs held by Indonesian teachers about the use of authentic materials for teaching reading in EFL context.

Borg (in Paltridge \& Phakiti, 2015) argued that beliefs held by teachers is part of teacher cognition that defined as social mental image of experiences which were reflected in teachers' decision of language instruction in their teaching practices. On the other hand, beliefs are considered as a set of proportions which are obtained from one's previous experience as a learner (Thomas, 2013).

In teaching a language, beliefs are the bridge between knowledge and action; between what have been known with what will be presented. Beliefs can present what knowledge which worth and should be presented in action (Larenas, et al., 2015). In fact, Kumaravadivelu (2012) discerned beliefs into two types, core and peripheral. Core beliefs is assumed to be more influential in shaping teachers' language instruction, while peripheral can cause incompatibility between what teachers assert they do and what they actually practice in the classroom. This becomes the indication as teachers' reflection of their beliefs. It is assumed that the compatibility between what beliefs held by teachers and how they practice their beliefs in classroom bases can help people understand of what teachers have understood and how they put the knowledge into action in teaching and learning process (Farrell, 2013).

Related to authentic reading materials use for teaching reading, beliefs held by teachers becomes the issue in EFL context. Teachers are expected to use authentic reading to stimulate their students' interest to read English text since the students will be assessed in the end of their learning stage. Therefore, in this study, the research question is addressed to explore the manifestation of teachers' beliefs about authentic reading materials:

RQ1. What are beliefs held by teachers about authentic reading materials?

\section{METHOD}

The research subjects for this study were four English teachers who teach English at senior high schools in Samarind. The researcher set the criteria for the sake of this study. All research subjects who were willing to take part in this study have more than 10 years teaching experience. They should be certified and followed more than one trainings or seminars in teacher's professional development. Before the interview and classroom observation were conducted, the teachers had submitted their consent form. They may in any time withdraw from this study as well, if they did feel comfortable.

Classroom observation, teaching documents prepared by the teachers, pre and post interview were used to obtain the data. The researcher made an audio recording and field note of the teaching reading practice and also transcribe the preinterview and post-interview in order to make the observation accurate. Before the researcher examined the classroom practices, pre interview to each teacher was conducted. This was done to administer the teachers' conceptions of authentic materials for reading used in the classroom practices. After that, the researcher observed the teachers' classroom practices to see the manifestation of teachers' beliefs about authentic materials for reading. Post interview was conducted to verify teachers' classroom activities with the data taken from the pre-interview and to clarify activities that do not compatible with the teachers' beliefs. The researcher classified and grouped the data based on themes emerged in this study.

\section{FINDINGS AND DISCUSSION}

Related to teachers' beliefs in using authentic materials for reading, three themes emerged, (1) types of authentic materials, (2) skills to be improved after reading, and (3) teachers' challenges of using authentic materials for teaching reading.

(1) Types of authentic materials

There are two types of authentic reading materials used by teachers in teaching literacy, print (in a form of flyer, flight schedule, menus) and auditory (songs) materials. It is assumed that authentic reading materials are not created specifically to be used in the classroom, but they are believed to become excellent learning tools for students to have an exposure to the real uses of language.

It is revealed from the interview, teachers believed that they quite often rely on their teaching materials from the textbook. It is a well prepared material for teaching. They admitted that they also used authentic materials to support their teaching practices, especially when they want to introduce their students how English words are used as a mean of communication.

They believed such printed authentic materials such as newspaper, flyers, magazines, maps, brochures, and invitation will assist students to be familiar with the real uses of English. The students will also learn new vocabularies from such text. They believed that by providing authentic materials students will be able to understand the text by looking at the medium used (Laurillard, 2013). This can be seen in the excerpt below. 
.....familiar with the real uses of English can help students to understand when and how to use words of English. (it is) easy for them understand the text when they see the real form...you know..for example when I teach the topic about "Giving information", it is easy when I bring like .. an invitation..and ask my student to give the information about the invitation...it's like catching their mind to speak about the topic...

In fact, based on classroom observation, it is noted that teachers mostly used song as authentic materials in the classroom. After the students listened to the song for several times, the teachers asked students to complete the missing words from the lyrics. Then two or three students were asked to read it aloud. In one of several meetings, the teachers highlighted some unfamiliar words to their students, or sometimes the teachers addressed to their students to identify unfamiliar words to be discussed classically. Based on the information from the lyrics, the teachers constructed questions. They did this to assess their students understanding of the song (Carter, et al, 2016).

...A song is a good medium to teach English. Everybody loves singing. This always success bring the mood of my class.

...it's pretty easy to find a song for teaching English words, the students learn how to pronounce, the vocabularies, the tenses...yes...I used some of sentences taken in a song to teach grammar....it always catch my students' attention....in fact, I have to be careful in choosing the song...

Only one teacher initiated to bring a travel magazine in her classroom. She admitted that she got the magazine when she travelled with a certain flight. She took it from the plane. She did that because she thought that she could make a use of the travel magazine in her class.

....I had this when I travelled by plain... I think this magazine can be used in my class...it is colorful, full of pictures and information about places in the world...I want students to be familiar with English by bringing the world to them ...

Despite the use of newspaper written in English can be one of sources of authentic materials, teachers found difficulties to find one in Samarinda.

.....For teaching reading, I knew I should use newspaper written in English because it has lots of texts which I could use to teach the comprehension of the text...however, it is difficult to find news agency selling that kind of newspaper...

In classroom practices, the teacher made a copy of texts taken from a magazine. She cut the texts into sentences. She asked students to arrange the sentences to be a good paragraph. She provided pictures to give cues.

Other teachers used songs to boost their students' interest to learn. Then, they use the lyrics of a song as a reading text. After listened to the song, they may ask students to read the lyrics loudly. They believed that this activity can help their students practicing their pronunciation.

(2). Skills to be improved after reading.

There are some skills improved after reading authentic materials, vocabulary knowledge, Scanning-skimming reading strategy, and critical thinking.

2.1 Vocabulary Knowledge

All teachers believed that authentic materials for teaching reading can increase their students' vocabulary knowledge (Kennedy, 2014). They offer wide range of vocabularies. Students can expand their knowledge of how to use the words in appropriate contexts. Teachers noted that authentic texts motivate students to acquire new words. It is often found that authentic texts use a different variety of text structures.

.......authentic materials covers a lot of vocabularies compare to textbooks, students may experience themselves with a wide range of words which they can learn when and what to use the words in (which) context...

This is one of good exposure for teaching students about latest information from the newspaper. Since textbooks need a long time before having revisions, magazines or newspaper are believed to have the most current information (Sham, 2016). Authentic reading materials can empower students with abundance of words that will enhance their use in the target language. Guo (2012) investigated that authentic materials can improve vocabulary knowledge, reading speed and reading habits. It is concluded that an increase of vocabulary affect students reading comprehension.

2.2 Scanning-skimming strategy

Students are believed to be able to practice scanning and skimming strategy when they read authentic reading materials. As a way to look at a text rapidly to get a general idea of the texts, skimming is needed for students. Teachers believed that students can improve their skimming strategy ability after they have massive exposure to authentic materials because it needs a greater degree of reading and word recognition skills (Urquhart \& Weir, 1998).

....Although skimming is always introduced every time.... my students must have as many as possible exposure of real texts because I want them familiar with the real uses of English....you know I believed it can help them since the students will find information that interest them...

Authentic materials provide interesting information for students about many things in daily bases. Therefore, they can practice skimming important information from authentic texts that interest them. Students can practice how to look only for general or main ideas, gather the information to get the summary about the text.

.....It is a good practice for students in which they can practice for their real life...they don't have to read for everything...just find the gist from the news...

Teachers believed that students can manage the time efficiently when they students how to skim the information. They are aware that this strategy can help students when they have to read a text in a specific time, such as in a reading test (Liaw, 2017). Along with skimming, scanning is another beneficial strategy that can be utilized. To comprehend the 
text, sometimes students have to be aware with specific information provided. Through scanning, students can practice how to get specific piece of information about the text.

(3). Critical thinking

Comprehending complex, content-rich text critically is an important necessity for students' academic performance and their life-long skill. However, they often fight very hard to comprehend these texts. As a matter of fact, this skill is required to complete such reading tasks, for example identifying information, analyze arguments, deriving inferences, or acknowledging the sources ( $\mathrm{Li}$, et al, 2016). The complexity in vocabulary and structures of authentic materials train students to understand the text. Consequently it leads students to think critically about the text.

......Yes it (authentic reading materials) consists of complex vocabulary and structure, but this is a good a way for my students to practice their critical thinking over the text.... you know sometimes they have a good imagination about the text...this happens when they are interested with the text or when they have known about the text...I mean they have previous knowledge about information provided in the text.

It is believed that authentic materials provide greater opportunities for real uses of English as a means of communication (Sánchez, Pèrex, \& Gómes, 2010). In addition, through authentic materials students are able to develop their understanding of cultures which it can derive their motivation to learn the language.

Teachers argued that critical thinking is very important when teaching a language in nowadays classroom. As the illustration, students were used to learn listen-repeat patter to acquire basic vocabularies when they were in a very basic level. It does not require critical thinking at all. However, as the students begin to progress their language understanding skill, they enter more complicated tasks which contains elements such as personalization, investigation and problem solving then they must have critical thinking to overcome them. To this point, authentic reading materials provide authentic communication which brings students' creativity to analyze and respond.

(4). Teachers' challenges of using authentic materials for teaching reading.

Authentic materials can be used as a medium for teaching a language since it can bring the content of life. This makes the language learning more meaningful. However, this is not easy to utilize authentic materials in classroom bases. This study identified challenges faced by teachers when utilizing authentic materials, they are (1) students' unfamiliarity to the topic, (2) cultural awareness introduction to students, and (3) lack of time in searching, selecting and modifying the materials.

4.1 Students' unfamiliarity to the topics

Students need their previous knowledge to help them understand the text. However, authentic materials often provide less familiar topic for students. Therefore, it is a teacher's responsibility to modify the topic of authentic materials to be suited to the students' background knowledge.

....the topics (of authentic materials) sometimes beyond students understanding, so, before I used it for my students I always modify it first....

Students often experience difficulty to understand the information provided in the text when they are unfamiliar with the topic (AlAzri, 2014). Reading a text needs an extensive background knowledge. This helps students to understand the topic of a text.

4.2 Cultural awareness introduction to students

Authentic materials often expose culture of English with less proportional to students' understanding. Therefore, teachers need to introduce the cultural awareness to students. The cultural background information is needed to understand the content of a text.

....explaining the cultural is a must, you know sometimes it is the text discussed about the topic that my students never have experienced before...like "Halloween", so I have to describe the culture before asking them reading the text..

Knowing the culture of target language can make students understood the adequately (Godwin-Jones, 2015). It is noted culture is part of language. Teachers should integrate culture when they teach a language. This is done so that students can build their linguistic and cultural competence of English.

4.3 Lack of time in searching, selecting, and modifying the authentic materials

Teachers need effort to search, select, and modifying the authentic materials. They admitted that they were able to do it in their spare time during teaching hour. In fact, the time is very limited because they found abundance of authentic materials that they can use (Asmari, 2015). However, they cannot use them all. They have to be selected and modified carefully to be suited to students' level.

.....I have to be smart managing my time to find authentic materials for my teaching....yes they are many...but still I can use them directly...I still need a modification so my students can learn from it...

Most of teachers seemed to use the authentic materials with a few modifications, in terms of level of vocabulary used for their students. They admitted that they cannot always modify the text. They often used as it is. This was because they needed time to accomplish the work. The lack of technological pedagogical knowledge competence also became one of their reasons. They expected to have training of integrating technology for modifying the text.

\section{CONCLUSION}


As an observable element, beliefs do determine teachers' decision in their teaching practices. It is assumed that beliefs aligned with the real practices.In fact, there are some conditions that make beliefs have to be adjusted to be implemented in classroom practices. This study revealed that teachers performed self-adjustment toward their own beliefs about the use of authentic materials for teaching reading. They limited their beliefs on students' capability to digest information and technical challenges when searching, selecting and modifying the authentic materials. Although, they agreed that authentic materials bring sufficient exposure of 'real world' to students, they cannot avoid using textbook as the main material for teaching. They admitted that authentic materials become the supplementary materials.

This study revealed that teachers should have a good self-determination in utilizing authentic materials since there are many aspects needed to be considered such as the vocabulary level, topic familiarity, cultural awareness, sufficient time, and technological pedagogical knowledge. For the latter, it is needed when teachers wanted to integrate authentic materials in a form of technology for their students. Students' level of vocabulary knowledge has to be the main consideration when searching, selecting, and modifying authentic materials. The vocabulary level should be suited to students' level. It becomes very challenging for students to read the text that beyond their knowledge. In fact, many authentic materials do not support this condition. Teachers should be able to make authentic materials adjustable to their students' level by simplifying or modifying the text to be accessible for students. Nevertheless, this becomes a challenge for because this activity takes time and energy to do. Instead of simplifying and modifying the text, teachers may simplify the reading process.

\section{APPENDIX. THE INTERVIEW PROTOCOLS}

\begin{tabular}{ll}
\hline A. & Teacher's Personal Information \\
\hline 1. & Tell me about yourself? \\
\hline a. & English learning experience \\
b. & Reasons to be English teachers \\
c. & Things remembered mostly about learning English \\
d. & Learning materials that affect the motivation to learn English \\
e. & Teachers' teaching strategy \\
f. & Learners' strategy to learn English \\
\hline 2. Teachers' concept of using authentic materials for teaching reading \\
\hline \multicolumn{3}{c}{ a. } & Types of authentic materials \\
b. & Way of searching, selecting and modifying \\
c. & Importance of using authentic materials \\
d. & Challenges of using authentic material \\
e. & Competences needed \\
\hline 3. Teaching reading \\
\hline a. & Reading activity stages \\
b. & Reading strategies
\end{tabular}

\section{REFERENCES}

[1] Abdulhussein, R. Y. (2014). Investigating EFL College Teachers' and Learners' Attitude Toward Using Authentic Reading Materials in Misan. Procedia-Social and Behavioral Sciences. Vol. 136. 330-343

[2] Ahmed, S. (2017). Authentic ELT Materials in the Language Classroom: An Overview. Journal of Applied Linguistics and Research. Vol 4. No. 2, 181-202

[3] Asmari, A. (2015). Communicative Language Teaching in EFL University Context: Challenges for Teacher. Journal of Language Teaching and Research. Vol. 6 No.5, 976-984.

[4] Azri, R. H. (2014). The Effect of Using Authentic Materials in Teaching. International Journal of Scientific \& Technology Research. Vol. 3. No. 10, 249-254.

[5] Beresova, J. (2015). Authentic Materials-Enhancing Language Acquisition and Cultural Awareness. Procedia-Social and Behavioural Sciences. Vol 192. 192-204

[6] Carter, H; Crawley, K; Townsend, D. R; Barone, D. (2016). Secondary Teachers' Reflection from a Year of Professional Learning Related to Academic Language. Journal of Adolescent \& Adult Literacy. Vol. 60. 325-334.

[7] Ersanli, C. Y. (2016). Improving Technological Pedagogical Knowledge (TPACK) of Pre-service English Language Teachers. International Education Studies. Vol 9. No. 5, 18-27

[8] Farrell, T. (2013). Reflective Teaching. Virginia: Tesol International Association.

[9] Guariento, W. \& Morley, J. (2001). Text and task authenticity in EFL classroom, ELT Journal, Vol. 55, No. 4, $347-353$

[10] Harmer, J. (2001). The Practice of English Language Teaching. $3^{\text {rd }}$ Edition. London. Longman

[11] Jones, R.G. (2015). Contributing, Creating, Curating: Digital Literacies for Language Learners. Language Learning \& Technology. Vol 19. No. 3, 8-20

[12] Kennedy, V. (2014). Critical Cultural and Multimodal Approches to Using Song as Literature in Language Learning. Libri \& Liberi Journal. Vol. 3. No. 2, 295-310.

[13] Kilickaya. F. (2004). Authentic materials and cultural content in EFL Classrooms. The Internet TESL Journal, Vol. 10 , No. 7. $1-6$

[14] Kumaravadivelu, B. (2012). Language Teacher Education for a Global Society. New York: Routlege. 
[15] Larenas, C. D., Hernandez, P. A., \& Navarrete, M, O. (2015). A Case Study on EFL Teachers' Beliefs About the Teaching and Learning of English in Public Education. Porta Linguarum. Vol. 23, 171-286

[16] Laurillard, D. (2013). Rethinking University Teaching: A Conversational Framework for the Effective Use of Learning Technologies. $2^{\text {nd }}$ Edition. Routledge. London and New York.

[17] Liaw, M. L. (2017). Reading Strategy Awareness Training to Empower Online Reading. The English Teacher Journal. Vol 38, 133-150.

[18] Paltridge, B., \& Phakiti, A. (2015). Research methods in applied Linguistics. A Practical Resources. Bloomsbury Academic. Sydney.

[19] Thomas, M. (2013). Teachers' Beliefs about Classroom Teaching-Teachers' Knowledge and Teaching Approaches. ProcediaSocial and Behavioural Sciences. Vol 89, 31-39.

[20] Tomlinson, B. (2012). Materials development for language learning and teaching. Language Teaching, 45(2), 143-179.

[21] Wong, V., Kwok, P., \& Choi, N. (1995). The use of authentic materials at tertiary level. ELT Journal, 49 (4). 318-322.

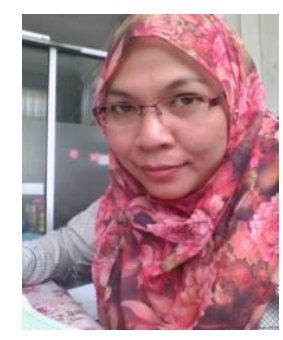

Desy Rusmawaty is a lecturer at the English Education Department of Mulawarman University. Indonesia. She accomplished her master's degree in Linguistics from Radboud University of Nijmegen, Netherland. Currently, she is pursuing her doctorate program in English Language Education at the State University of Makassar. Her research interest is in Teaching Reading in EFL Context and Teachers' Professional Development.
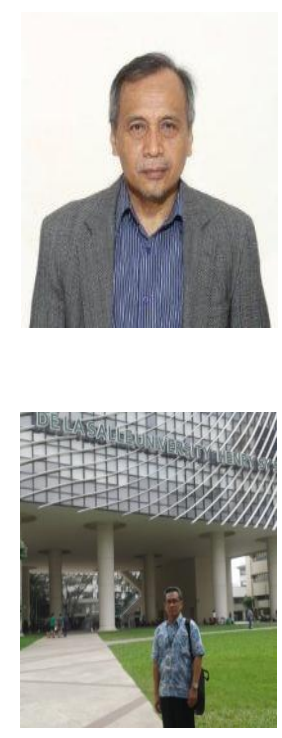

Haryanto Atmowardoyo is a professor and head of the English Language Education Post Graduate Program at the State University of Makassar. He completed his master's degree in English Language Education from the State University of Malang. He obtained his doctorate degree of English Language Education from the State University of Jakarta, Indonesia. Currently, he is the Chief Editor of English Language Teaching ELT Worldwide.

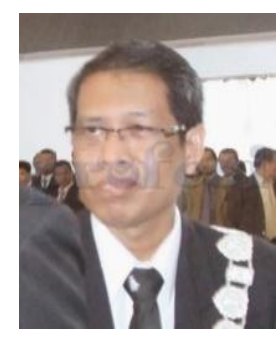

Nurdin Noni is a professor and a lecturer of English Education Program at State University of Makassar, South Sulawesi. He is interested in Curriculum Design and Development of ELT.

Arifuddin Hamra is a professor at the State University of Makassar. He completed doctorate degrees in the field of Reading in EFL Context at the Hasanuddin University, Makassar. He has been teaching English more than 35 years at teacher training college. 